\title{
TANÍTÓSÁG A KORABELI BULVÁRSAJTÓ TÜKRÉBEN AZ 1930-AS ÉVEK HAJNALÁN
}

\author{
Szerző: \\ Frank Tamás \\ Semmelweis Egyetem (Magyarország) \\ Szerző e-mail címe: \\ frankta72@yahoo.com
}

\section{Lektorok:}

Dr. Pintér Henriett, Semmelweis Egyetem (Magyarország)

Horváthné Kállay Zsófia Semmelweis Egyetem (Magyarország)

Frank Tamás (2018): Tanítóság a korabeli bulvársajtó tükrében az 1930-as évek hajnalán. Különleges Bánásmód, IV. évf. 2018/3. szám, 39-54. DOI 10.18458/KB.2018.3.39

\begin{abstract}
Absztrakt
Az 1930-as évek elejének tanitói ethoszának, a népiskolai tanitóság professzionalizálódásának folyamata már komoly szakirodalommal rendelkezik, de érdekes más aspektusból is vizsgálat tárgyává tenni a korszak alábecsült szakértelmiségét.

Kutatásunk a 30-as évek elsö felének két legnagyobb olvasótáborával rendelkezö bulvárlapjának elemzésére vállalkozott. Az amerikai típusú bulvárlapi hagyományokat követö Az Est politikailag független lapként kiemelkedö nagyságú és minöségü tudósitói hálózatával próbálta meg piacvezetőként tájékoztatni, szórakoztatni olvasóközönségét. Az 1915-ben indított 8 Órai Ujság kormányközeli bulvárlapként definiálta magát. Kimondottan Az Est konkurenciájaként indult. Mindkét orgánum jelentös olvasótáborral rendelkezett, ezért véleményformáló, diskurzusteremtö erejük vitathatatlan. A politikai téren eltérö orientációjú, de szerkesztési elveik mentén egyezö lapok esetében érdekes lehet annak felfejtése, hogy milyen - a tanitóságot, a tanitókat érintö - tartalmakat exponáltak az olvasóközönségeik elé; milyen szakmai tartalommal jelentek meg a bulvárlapok hasábjain az elemi oktatásra fókuszáló cikkek, a tanitókról, a pedagógiai tevékenységről szóló irások. Milyen a konnotációja az érintett cikkeknek, milyen képet festenek a tanitókról az olvasók számára?

Külön figyelmet szenteltünk annak, hogy feltárjuk, a fogyatékkal élö gyermekekkel foglalkozó tanitók és intézményeik hogyan és miként jelennek meg a vizsgált lapokban. Reményeink szerint nemcsak megismerhetjük a néptanitók problémáit, szakmai sikereiket és nehézségeiket, de az érintett cikkek segitségével bepillantást nyerhetünk a kor politikai és közhangulatába is.
\end{abstract}

Kulcsszavak: 1930-as évek, tanítóság, tanítók, bulvárlapok, reprezentáció

Diszciplina: neveléstörténet

\begin{abstract}
The pedagogue's ethos and the process of professionalization of elementary school teaching in the early 1930s already has a serious literature, but it's also interesting to examine the underestimated expertise of the era in other aspects.

The goal of our research was to analyze the contents of two tabloids which had the largest reading camps in the first half of the $30 \mathrm{~s}$ on the subject of teaching. Following the American-style tabloid traditions, 'Az Est' was a politically independent journal which tried to inform and entertain its readers as market leader with an outstandingly large and qualitative correspondent network. The '8 Órai Újság' - founded in 1915 - defined itself as a tabloid close to the government. It
\end{abstract}


identified itself specially as the concurrency of "Az Est". Both of these had remarkable readership therefore their opinion-shaper, conversation-creater power is indisputable. Unfolding the quality of their professional content, which are focusing on primary education, pedagogues and their activities, could be intriguing. What is the connotation of the mentioned articles, what kind of picture do they paint of the pedagogues in the eyes of the reader?

We paid particular attention to reveal how do teachers and institutions working with children with disability appear in the papers. We hope that we can not only learn about the problems of the pedagogues, their professional successes and difficulties, but also with the help of the articles we can gain insight into the political and public sentiment of the era.

Keywords: 1930s, pedagogues, press, tabloid, representation

Disciplines: pedagogy

A hazai néptanítóság professzionalizációs törekvéseinek, illetve folyamatának neveléstörténeti feldolgozása jelentős részben már megtörtént. Elégséges Németh András (2004, 2010, 2013), Pukánszky Béla (2004, 2016), Kelemen Elemér (2007), Szabolcs Éva (2011), Baska Gabriella (2008, 2011, 2016), Pornói Imre (2014) pedagógiaitörténeti, tanítótörténeti kutatásait megemlíteni, de Donáth Péter (2008), Kelemen Elemér levéltári alapokon nyugvó kutatásai is újabb rétegét mutatták meg az egyébként is sokszínü tanítóságnak. A vizsgálatok további aspektusa a szociológiai megközelítés, melynek révén tovább színesedett a tanítóságról alkotott kép: Gyáni Gábor (2006), Karády Viktor (2012), Nagy Péter Tibor (2011). Természetesen a kiragadott kutatókon kívül is sokan, sokféleképpen vizsgálták, vizsgálják a tanítóság kialakulásának, fejlődésének, szakmásodásának történeti vonalát.

Hazánk XX. századi első felének történelme bővelkedik olyan eseményekben, melyek alapvetően szabták át - gyakran radikális módon - a társadalmi és így az oktatási-nevelési status quot. A „,boldog békeidőket” és a millenniumi időszakot követő politikai hullámverés, majd az I. világháború és az azt követő békeszerződés, a Horthy-korszak, a politikai jobbratolódás évei, Magyarország fasizálódása, majd belépés a II. világháborúba mind olyan esemény volt, mely komoly hatást gyakorolt az oktartási alrendszerre is.

Az Eötvös- féle népiskolai törvény bevezetése óta (1868) a tanítóság szakmásodása a vizsgálatba bevont tágabb időszakra már befejeződött.

Célunk a két világháború közötti, a Horthy-korszak időszakában a praxisban tevékenykedő néptanítóság vizsgálata volt. Kutatásmetodológiai megfontolások miatt a vizsgált időszakot tovább szűkítettük az 1930-1934 közötti évekre. Ennek indoka, hogy érdemesnek tartottuk a Klebelsberg Kuno-féle oktatási kormányzat utolsó éveinek (1930-1932) és a Hóman Bálin-féle paradigmaváltás első éveinek (1933-34) vizsgálatát, feltárását, amennyiben lehetséges, ütköztetését. A szakpolitikai változások mellett a tanítóság helyeztét nehezítette a gazdasági világválság megjelenése, mely egészen 1934-ig elhúzódott, és kormányzati színtü problémaként jelentkezett az elégedetlen néptanítói tömegek miatt.

A társadalmi-gazdasági-technológiai változások révén a tanítóság reprezentációja új területeken is megjelent, illetve felerösödött, így lehetővé teszik a kutatók számára, hogy újabb színtereket beemelve a kutatási területek közé, láthatóvá váljon, hogyan élte mindennapjait ez a szakmai réteg, illetve a társadalom számára milyen pedagógiai területek voltak diskurzusteremtők. Diskurzusteremtő felületként tekinthetünk a pedagógiai szaksajtóra, melynek elemzésére az elmúlt években került sor. A Néptanítók Lapja kiemelt szerepet kapott ebben a folyamatban.

A tömegmédiumok diskurzusteremtő ereje vitathatatlan, hiszen például „1894-ben 735 magyar hírlap és folyóirat jelent meg" (Buzinkay, 2009, 19.). Joggal feltételezhetjük, hogy a nagy olvasótáborral rendelkező tömegmédiumok megjelenése, elterjedése alapjaiban formálta át a társadalmi kommunikációs teret. Témaválasztásaikkal befolyásolták a közízlést. 
A századfordulóhoz képest az I. világháborút követően - a területcsökkenés és a gazdasági recesszió következtében - a lapok számát tekintve rövid ideig visszaesést tapasztalhattunk, de a 20as évek közepére újból mind a példányszámok, mind a kiadott lapok számát illetően emelkedés történt: a korszak domináns kommunikációs csatornája továbbra is az írott sajtó maradt. A rádió elterjedése bár dinamikus volt, de messze nem minden társadalmi közeg számára volt elérhető még ekkor.

A vizsgált időszakban (1930-1934) tehát továbbra is a kommunikációs tömegmédium a sajtó volt. Kutatásunk során - a nagy olvasótábor megléte miatt is - a bulvárlapok tanítóságot érintő cikkeire fókuszáltunk. Előzményként két korábbi kutatás említhető: Szabolcs Éva (2001) feltáró munkája, melynek során dokumentumforrásként a Néptanítók Lapjában megjelent (1901) tanítói álláshirdetéseket vizsgálta, illetve $A$ tanitói szerep hírlapi reprezentációja tárgykörében született (Baska, 2016).

A vizsgálat újszerüsége a bulvárlapok feldolgozására tett kísérlet. A bulvárújság-írás és -kiadás populáris sajtómüfaj, így a mainstream forrásfeldolgozás mostohaként tekintett rá, miközben kiemelkedő olvasótáboruk révén nemcsak szemlélet- és ízlésformáló, hanem politikai tényezők is voltak.

Az Est és a 8 Órai Ujság az időszak kiemelkedő olvasótáborával rendelkező lapjai, bulvárlapjai. Témaválasztásaik számunkra is jelzésértékkel bírnak. Reprezentációs felületük informatív: hogyan és miként, milyen konnotációval jelenik meg a tanítóság.

Tanulmányunkban elöször történelmi és oktatáspolitikai kontextusba helyezzük a kérdéses időszakot, ezt követően exponáljuk a tanítóság, a néptanítók gazdasági és társadalmi helyzetét, majd az érintett időszak tömegkommunikációs trendjét, jellemzőit mutatjuk be a diskurzus keretébe ágyazva, valamint a kutatás keretére is kitérünk. Végül a két bulvárlap rövid bemutatásával zárjuk az elméleti részt. A tanulmány második egységében bemutatjuk, miként jelent meg az olvasóközönség számára a néptanító, milyen kép rajzolódik ki a tanítókról az utolsó klebelsbergi és az első hómani évek alatt. Felsejlik szakmai és civil életük. Mindeközben reményeink szerint a korszellem is feltárul előttünk.

\section{A történelmi kontextus}

Az I. világháborút lezáró trianoni békeszerződés alapjaiban határozta meg a két világháború közötti Magyarország nemzetközi kapcsolatrendszerét, politikai és közgondolkodását.

Horthy Miklós hosszúra nyúlt kormányzósága alatt (1920-1944) a bethleni konszolidáció tízéves időszakában is megfigyelhető volt, majd az 1930-as évek elejétől tovább erősödött - a Gömbös Gyula nevével fémjelzett politikai jobbratolódás éveiben is - a belpolitikai diskurzus tematizálása. A lassú fasizálódás útjára lépő ország kormányai pedig egyértelművé tették az irányvonalat - például az újságbezárásokkal, államosítással - ezzel kijelölve a kommunikációs határokat. Ez a tematizálás a kultúra, az oktatás, a nevelés területén is megjelent, és a békediktátum okozta sokkot követően - főleg a nemzeti identitáskonstrukció folyamatában - az évek során egyre eröteljesebbé vált.

Bethlen István miniszterelnöksége (1921-1931) alapvetően a trianoni trauma kezelésén, majd a királykérdés problematikáján át, a gazdasági világválság magyarországi betetőzéséig tartott. A tízéves ciklus hatalmas erénye - sok egyéb mellett -, hogy az új határok közé szorított ország, amely elvesztette korábbi területének jelentős részét, ipari termelésének közel 60 , mezőgazdasági termelésének 40 százalékát, képes volt kitörni a külpolitikai elszigetelődésből. Sajnos a világválság olyan elemi erővel csapott le a társadalom szinte minden szegmensére, hogy esélytelennek tünt a kormány politikai túlélése a kiábrándult, sok helyen éhező, munkanélküli százezrekkel a háttérben (Romsics, 1996.). A válság miatt az állami szférában jelentös bércsökkentésre is sor került, valamint a bankrendszer összeomlását elkerülendő háromnapos bankzár is bevezetésre került 1931. július 13-án, de Bethlen és kormánya számára tartós - politikai értelemben vett - túlélést ez a megoldás sem jelentett (Romsics, 1996). 
A Bethlent követő Károlyi-kormány után Horthy Miklós kormányzó Bethlen honvédelmi miniszterét, vitéz Gömbös Gyulát bízta meg a kormányalakítással. A többféle politikai platformon is megforduló Gömbös (pl. Magyar Országos Véderő Egylet, Anti Bolsevista Comité) a lakosság körében kiemelkedő személyes támogatottsággal rendelkezett. Ezt a szimpátiát tovább erősítette származása is, hiszen szülei nem a politikai-társadalmi elit tagjai voltak: édesapja egyszerü falusi evangélikus tanító volt. A Bethlenhez képest radikálisabb nézeteket valló politikus alapvetően kívánta átformálni a konszolidáció időszakának politikai status quoját: tekintélyuralmi állam kiépítésére tett lépéseket, továbbá jelentősen növelte a honvédelmi kiadásokat.

A korszak miniszterelnökeihez hasonlóan a vallás- és közoktatásügyi miniszterek is markáns személyiségek, kiforrott oktatási, nevelési elveket valló közgondolkodók voltak: gróf Klebelsberg Kuno tíz éven át (1922-1931), Hóman Bálint két cikluson keresztül (1932-1938; 1939-1942) miniszterként a korszak megkerülhetetlen személyiségei voltak. Mindkét szakpolitikus az oktatásnevelés prioritásként való kezelésében látta a magyar felemelkedés Trianon utáni útját, a revizionista politika megvalósításának esélyét, de eltérő alapkoncepció mentén vélték megvalósítani azt.

Klebelsberg a kultúrfölény eszméjét hirdette, miszerint a müvelődésünk, müveltségünk fejlesztése révén kerülhetünk a szomszédos országok fölébe (Pukánszky és Németh, 2001), ezért legfőbbképpen az analfabetizmus felszámolását tüzte zászlajára. Hatalmas népiskola építési hullám vette kezdetét. Horthy és Bethlen politikai támogatásával elérte, hogy a költségvetésből 1925 és '30 között évente 9-10\% jusson a Vallás- és Közoktatásügyi Minisztériumnak (Romsics, 2010). Azért azt fontos megjegyezni, hogy a kiemelkedően magas oktatási büdzsé egyik oka a leventemozgalom oktatási költségvetésbe ágyazott finanszírozása volt, mivel a trianoni békeszerződés tiltotta a sorkötelezettséget, ezért a militáns képzési jelleget elbújtatták az iskolákban a testnevelést szolgáló leventeképzés mögé (Pukánszky és Németh, 2001; Palló, 2007). A jelentős állami támogatás révén gomba mód szaporodtak főleg a kis tanyai iskolák az országban (Ujváry, 2012), továbbá a városi, külvárosi iskolák száma is emelkedett. Az expanziónak látható-érezhető hatása lett az írni-olvasni tudók számában: míg az 1920-as években az analfabéták aránya több, mint 10 százalék volt, addig 1930-ban országosan $9 \%$-ra csökkent, mely komoly regionalitásbeli különbségeket mutatott (Romsics, 2010; Szabó, 2008; Ujváry, 2012).

Az oktatáspolitikai sikerek ellenére a gazdasági világválság oly’ mértékben megrengette a magyar gazdasági potenciált, hogy bár az oktatás fundamentuma nem változott, az egzisztenciális létbizonytalanság, az elszegényedés, az alkalmazottak körében megjelenö bércsökkentés komoly politikai problémát okozott, amely magával sodorta Bethlent és közoktatásügyi miniszterét, gróf Klebelsberg Kunót.

Az új miniszter, Hóman Bálint a nemzetnevelésben, a nemzetté nevelésben vélte megtalálni az új Magyarország felemelkedésének eszméjét, Klebelsberghez hasonlóan a keresztény Magyarország ideája mentén. Oktatási programja a jellem- és erkölcsnevelés, a nemzeti tantárgyak dominanciájának és tananyagtartalmának erősítését célozta meg. Bevezette az osztályfönöki óra intézményét, megemelte a testnevelésórák számát (Ujváry, 2012). A minisztérium politikai és gazdasági támogatása továbbra is egyértelmü volt, hiszen a klebelsbergi korszaknál is nagyobb arányú büdzsével részesedett a minisztérium az állami költségvetésböl: 1932-1933 13\%; 1934-35 12\% (Benisch, 1930; Romsics, 2010.) Természetesen a válság elhúzódása miatt az összeg nominálértéke jelentősen csökkent. A gazdasági összeomlás hatásai egészen a 30-as évek közepéig elhúzódtak, és igen komoly feszültségek, szinte éhínségközeli állapotok voltak a legszegényebb tanyai vidékeken, de a városok lakossága is igen komolyan megsínylette a túltermelési válság pénzügyi következményeit, mely a közhangulatot is erösen befolyásolta. Gömbös realitásérzékét, valamint politikai bátorságát jelezte, hogy eltörölte a válság miatt Bethlen által bevezetett statáriumot, mivel felismerte, hogy az elégedetlenség nem a hatalmi elit, a politikai berendezkedés ellen irányul, hanem a gazdasági problémák, nehézségek megoldását sürgetik az elégedetlenkedök. 


\section{Néptanítók-tanítók helyzete}

Az I. világháborút lezáró békeszerződésbe foglalt területcsökkenéssel arányosan csökkent az iskolák száma is, de a gyermeklétszám nem csökkent ekkora mértékben, ezért az egy tanítóra jutó diákok száma 1920-as és a 1930-as években is 52 fö körül volt (Romsics, 2010). Amennyiben kiemeljük az egyébként kiemelkedően jónak számító Budapest számait, akkor már 68 diák/tanító az országos arány (Benisch, 1930; Pornói, é.n.)! Az I. világháború alatti demográfiai csökkenést követő újbóli születésszám-emelkedés hatására az elemi népoktatási tanulólétszám 1931-ben érte el tetőpontját, ami ezt követően ismételt csökkenésnek indult (Benisch, 1930), így a tanítói létszámra is hatást gyakorolt. További probléma volt az országban tapasztalható egyenlőtlen tanítói eloszlás, valamint az ország különbözö területei között az eltérő munkakörülmények, melyek leginkább a tanyai közegben dolgozó tanítókat sújtották. Ezért nemcsak az infrastruktúra okolható, hanem a hazai iskolaszerkezet is: a tanyai iskolák részben osztott ( 2 tanító) vagy teljesen osztatlan (1 tanítós iskola) oktatási rendben müködtek. Az ország elemi iskoláinak több, mint 70 százaléka egy vagy két tanítóval müködött, tehát osztatlan vagy részben osztatlan volt (Romsics, 2010), mely szakmailag komoly kihívás elé állította az érintett - föleg tanyai - tanítókat. A városi iskolák alapvetően többtanítós rendben oktattak.

A tanyai tanítók munkakörülményeit, szakmai nehézségeit tovább fokozta az a körülmény is, hogy az iskolakerülő kisdiákok föleg a vidéki, kistelepülési, illetve tanyai közegben müködő oktatási intézmények körzetébe tartoztak. Bár a húszas évektől kezdve az iskolakerülő tanulók arányának folyamatos csökkenése tapasztalható az országban, 1920-ban 17\%, 1930-ban 2-5 \% (Benisch, 1930), a mezőgazdasági, főleg idényjellegü munkavégzés időszakában - a családi gazdálkodás érdekében - gyakran maradoztak ki az oktatásból az érintett diákok, mely nehezítette a tanítók munkavégzését, a szakmai előrehaladást (Szabó, 2008). Ennek fényében különösen értékes eredménynek számít az alfabéták arányának javulása.

Szintén komoly feszültséget okozott a heterogén intézmény-fenntartói struktúra (államifelekezeti), mely a javadalmazás, az eltérő elvárások tekintetében okozott országos szintű eltéréseket (Baska, 2011), és igen komoly feszültséget, főleg a válság időszakában. Az elemi iskolák kétharmada ugyanis egyházi fenntartású volt, de a tanítók fele volt csak egyházi fennhatóság alatt. Az egyházi fenntartás alatt müködő iskolák tanítói a bérük egy részét terményjárandóságban kapták, mely a válság hazai megjelenését követően nagy mértékben inflálódott. A fenntartói struktúrában meglévő kettősség is nehezítette a helyzetük rendezését, hiszen a kormányzat csak az állami fenntartású iskolák tanítói esetében vállalt teljes felelősséget (Ujváry, 2012), mely a gazdasági világválság időszakában inkább csak ígéret volt, mint valós pénzügyi felelősségvállalás. Az egyházi fenntartású iskolák pedagógusai, és így tanítói esetében a politikai szándék tetten érhető volt a bérkifizetések rendezésére vonatkozóan, de tényleges kormányzati beavatkozás elvétve történt.

\section{A tömegkommunikáció és a sajtóorgánumok jellemzői}

A tömegmédiumok esetében a hatalom nem csak jelképes, hanem konkrét. „Az a szemlélet, mely a sajtót hatalmi ágnak tekinti, az 1810-es évekre nyúlik vissza" - véli Buzinkay Géza a Magyar Sajtótörténeti Antológia 1780-1956 elöszavában (2009, 14. o.).

Az 1900-as évek fordulóján több, mint 700 magyar sajtóorgánum volt jelen (Buzinkay, 2009), melyből Pesten 384 jelent meg a millennium évében (Lipták, 1997). Az I. világháború alatti és az azt követő néhány évben tapasztalható visszaesés után - a bethleni konszolidáció éveitől kezdődően - ismét növekedésnek indult a lapkiadás, és „1922-től csaknem ugyanannyi új kötetcím és napilap vagy periodika jelent meg, mint a történeti hazában” (Ujváry, 2012). Az I. világháborút követő ismételt sajtókonjunktúra egyértelmúen jelzi, hogy a különböző orgánumok olvasása a lakosság egyre szélesebb körében napi létszükségletté vált.

A Horthy-korszak és az azon belül is vizsgálat tárgyává tett időszak kommunikációs csatornái továbbra is a sajtóorgánumok voltak: szaklapok, politikai napi- és hetilapok, családilapok, periodikák, bulvárlapok, vicclapok. A legnagyobb példányszámot elérő újságok több százezres 
olvasótáborral rendelkeztek, így véleményformáló szerepük vitathatatlan (Lipták 1997; Buzinkay, 2009).

Nem véletlen, hogy a két világháború közötti időszak majd minden politikai pártja, szerveződése, fajsúlyosabb társadalmi szereplöje törekedett lapkiadásra, hiszen a sajtónak három fö funkciója van: informálás, véleményformálás és szórakoztatás (Buzinkay, 2016). Ebből az első kettő (informálás, véleményformálás) erösen érzékeny a politikai ideológiákra. A lapok célja politikai, ideológiai irányuk kommunikálása, illetve a velük szimpatizáló olvasóközönségük identifikációjának erősítése.

A tömegsajtó által megjelenített tartalmak befolyásolják olvasóközönségük szemléletét, ismereteit. Viszont a befolyásolás két irányú, hiszen az újságolvasók vélt és valós igényeinek kielégítése egyben kihat a szerkesztési elvekre, koncepciókra. A piaci körülmények között müködő lapoknak szükséges érzékenyen reflektálniuk a társadalmi, ebben az esetben az olvasói igényekre. Ez a trichotómia (lapkiadói orientáció-olvasói igények-gazdasági eredményesség) a szerkesztőktől alapjaiban feltételezi a rugalmas hozzáállást, feltáró és interpretatív témaválasztást és témakezelést. Egyetértve Lipták Dorottyával (1997) „a társadalom nem csupán befogadója, hanem alkotója, szabályozója és felhasználója is az újságnak”. Baska Gabriella által említett szemlélettel azonosulva „immár nem a társadalom, az etnikumok vagy a történelem a vizsgálat tárgya, hanem a megnyilatkozásaiban megnyilvánuló ember [...], a szövegként létező történelem” (Baska, 2011, 65. o.).

Továbbá Géring Zsuzsa meglátásával is azonosulni tudunk, bár szüken vett értelemben nem tartalomelemzést végeztünk: „a szövegeket önmagukon túlmutató jelenségként kezeljük, olyan entitásokként, amelyek révén a beszélők/írók, a szövegek alkotói az őket körülvevő - tárgyi és társadalmi - világot létrehozzák és felépítik" (Géring, 2014, 11. o.).

\section{A kutatás kerete}

Az 1910-ben indított Az Est, klasszikus amerikai bulvárújságírói hagyományokra építő, profitorientált sajtótermék volt. Tulajdonos-föszerkesztője: Andor Miklós újságíró volt, aki kiváló érzékkel tapintott rá az újságolvasói igényekre. A politikai pártoktól független, gazdasági alapokon nyugvó lapkiadó naponta három orgánummal jelentkezett: a Magyarország, Az Est és a Pesti Napló. A lapok újszerüsége a tipográfián túlmenően az olvasói igényekre rezonáló szerkesztési elvek voltak: tudósítói hálózata, újságíróinak szakmai minősége eredményes lappá tette: az indulást követően hamarosan elérte a napi 200.000 (Buzinkay, 1997), az I. világháború alatt a félmilliós példányszámot (Arcanum), 1935-ben - Andor halálát követően - is 150.000 példányban jelent meg.

A 8 Órai Ujság 1915-ös megjelenésekor Az Est konkurenciájának szánták. Független lapként definiálta magát, de a harmincas évekre Bethlen házibulvárjaként tekintettek rá. Mindkét lap ára 10 fillér volt (Klein, 2016).

Az újságcikkek müfaji kategóriái a következők voltak: riportok, tudósítások, hírek és vezércikkek, illetve olvasói levelek.

Az Arcanum Digitális Tudománytár forrásbázisában a „tanító” kifejezés Az Estben az érintett időszakban 631-szer, a 8 Órai Ujságban 698 alkalommal szerepelt. A „tanítónő” kifejezés Az Estben 328-szor, a 8 Órai Ujságban 232-szor. Természetesen igen sok átfedés, duplum tapasztalható. A bemutatott tartalmak a kutató szubjektívizmusát mindenképpen jelzik, de törekedtünk arra, hogy a pedagógiai kérdésekben alapvetően laikus bulvárlapi olvasótábor számára hírértékkel bíró, domináns tartalomtípusokat jelenítsük meg, illetve azokat, melyek tipográfiai, szerkesztői kiemelés következtében diskurzusteremtők lehetnek, vagy a tanítóságról kialakult képet befolyásolni képesek. Az időszak két bulvárlapjának tanítóságot érintő tartalmai esetében a szerzők homályban maradtak, mivel általában „Az Est tudósítójától”, illetve a 8 Órai Ujság esetében „saját tudósítónktól” forrásmegjelölést használták. 
A vizsgált időszak szakmapolitikai érdekessége - a gazdasági világválság nehézségein túl -, hogy a klebelsbergi oktatási koncepció gyengülése, illetve az azt követő hómani oktatáspolitikai paradigma erősödése egyidejűleg volt jelen ekkor. A szakpolitika által kívánt koncepcióváltás hogyan és miben nyilvánult meg? A történelmi kontextust elhagyva - a hétköznapi pedagógust figyelve - milyen ügyek érdekelték a tanítókat? Mi foglalkoztatta őket, illetve milyen diskurzusok esetében jelent meg a szereplő tanítói státusza? Milyen diskurzusok folytak a közösségeikben? Aktorként milyen minőségben jelentek meg a kommunikációs csatornákon? Az újságszerkesztők milyen témaválasztásokat preferáltak és ezek a tartalmak milyen állapotokat közvetítettek a tanítóságról?

Célunk az orgánumok cikkein keresztül bemutatni a korszak tanítóságát, annak szem elött tartásával, hogy történetileg ismert a lapok tulajdonosi köre; politikai-gazdasági érdekük sejthetö.

\section{A kutatás eredményei}

\section{Tanítók kriminalizálódása}

A tartalomelemzés szempontjából a tanítókat érintő cikkek legnagyobb számban a bünügyi kategóriába tartoznak. És ez abban az értelemben is igaz, hogy nem csak elkövetőként jelennek meg a cikkekben, hanem áldozatként is gyakran szerepelnek tanítók a lapok hasábjain. A bünügyi hírek mennyiségére magyarázatul szolgálhat a lapok müfaji jellege, hiszen bulvárlapként céljuk a minél nagyobb olvasótábor megszerzése, és ez a figyelemfelkeltő, könnyen érthetö, izgalmas hírek révén érhető el.

$\mathrm{Az}$ áldozattá válásra jó példa Az Est és a 8 Órai Ujság által is alaposan tárgyalt hír: „szerelemféltés miatt gyilkosság áldozata lett a hatvani tanító” (Az Est, 1930.01.26., 3. o.). Bünügyi esemény kategóriába sorolható Az Est azon cikke, miszerint „Kucsera tanító bicskás támadói a bíróság előtt" (1930.04.11., 5. o.). A hírnek politikai felhangja is van, ugyanis a támadók a szélsőjobboldali Ébredő Magyarok Egyesülete „sasok” csoportjának tagjai voltak, akik a kántortanítót zsidóbarátsága miatt támadták meg. A terjedelmes cikk rávilágít arra, hogy a tanító „tanórai viselkedése”, szemlélete kimerítette a szélsőjobboldali csoport tagjai körében az árulást, a magyarság elárulását, mivel a tolerancia, az egymás mellet élés fontosságára hívta fel a figyelmet a tanító az óráin.

Szintén az áldozat professziója miatt kívánkozhatott a bulvárlapok oldalára mindkét lapban: „öngyilkos lett a pásztói tanítónő. Óráját rendben megtartotta, jegyben járt egy cementgyárossal” (Az Est, 1930.09.27., 9. o.). „Több levelet hagyott hátra, amelyekben azt írja, hogy idegei felmondták a szolgálatot és kéri, hogy ne boncolják fel” (8 Órai Ujság, 1930.09.27., 4. o.).

A cikk explicit közlendőjén túlmenően, implicit jellege is informatív - méghozzá két területen is - a számunkra: a társadalmi mobilitás bizonyos eseteire mutat rá, mivel a középosztályba nem tartozó tanító(nő) (Kövér és Gyáni, 2006) egy gazdasági értelemben véve középosztálybeli férfival kötött házassága révén magasabb presztízsủvé válhatna. A másik mélyebb aspektus, a tanítói morál területe, hiszen ,óráját megtartotta”, és csak utána - teljesítve szakmai kötelezettségét - vetett véget életének.

A két világháború közötti társadalmi szerkezet alapján elmondható, hogy a tanítóság közel 20.000 főt számláló, alapvetően homogén csoportja (Nagy, 2002) nem tartozott a társadalmi középosztályba, de még az értelmiségi középosztályba sem (Kövér és Gyáni, 2006), de „kapcsolati hálójuk”, illetve a professzió adta ismertség révén „volt kitörési lehetőségük a társadalmi elszigetelődésből" - például egy házasság révén. Továbbá a tragikus hír bulvárjellegén túl szerkesztői szempont lehetett, hogy a tanítók az újságolvasókhoz közelállóknak tünhetnek, mely a szerkesztési elveknél prioritást jelenthet. 
A büncselekmények elkövetésével vádolt tanítók és hozzátartozóik szinte minden büncselekménytípust megvalósítottak. Tettlegesség: „A jobbágyi tanító feleségének pöre az esperes-plébános ellen" (Az Est, 1930.03.12., 6. o.). A tanítót meggyanúsították szemérem elleni vétséggel, erre a tanító felesége az esperest bosszúból meg akarta korbácsolni a templom előtt, mert az egyházfi a szószékről terjesztette a tanítót (férjét) inszinuáló hírt.

Ennél tragikusabb és fajsúlyosabb ügy is megjelent a lapok oldalain, mégpedig visszatérően: 1930. május 28-án ,áll bíróság elé az öcsödi tanítóné, aki elégette férjét” (Az Est, 1930.05.28., 5. o.). A háttérben egy szerelemféltés állhatott, mely konfliktust a fiatal feleség és az idősebb tanító nem tudta kezelni: ,az asszony újból veszekedni kezdett vele, majd kirohant a szobából és rázárta az ajtót a férjre. A tanító véletlenül feldöntötte a petróleumlámpát" és bent égett a házban (8 Órai Ujság, 1930.05.28., 7. o.).

Sajnos a '30-as évek sem mentesek a vállalhatatlan, szexuális visszaélést sejtető esetektől. Az Est és a 8 Órai Ujság is tájékoztatta olvasóit a következő esetről: A tanító a gondjaira bízott neveltjeivel kezdeményezett testi kontaktust: „A zalaszentbalázsi tanító bünügye - Furcsán viselkedik a tanító bácsi - diákok, tanítónő tanúvallomása" - szól a tudósítás címe (Az Est, 1931.03.11., 13. o.). „A bíróság Mészáros tanítót bűnösnek mondotta ki hatrendbeli szemérem elleni vétségben és ezért háromhónapi fogházra és a felmerült költségek megfizetésére ítélte" (8 Órai Ujság, 1931.03.14., 6. o.).

Hasonló eseményt tár olvasói elé Az Est több terjedelmes cikkben 1931 decemberében és a következő évben: „Három évre ítéltek egy lelketlen tanítót. A múlt év telén suttogni kezdtek, hogy Zubek István tanító megrontja kis leánytanítványait. A csendőrség nyomozása megállapította, hogy a híresztelések igazak. A szegedi törvényszék [...] zárt tárgyalás után most hirdetett ítéletet a bünös tanító ügyében" (1932.11.3., 10. o.). Az érintett tartalmak egyértelmüen jelzik, hogy az esetek társadalmi és büntetőjogi megítélése ekkorra már egyértelmüvé vált, a szakmai kánon körbehatárolta a pedagógus, tanító felelősségi körét, lehetőségeit, szakmai és emberi mozgásterét a szakmai interperszonális térben.

Az időszak gazdasági-társadalmi hátterét, illetve a korrupciós viszonyokat jól jellemzi az a büneset, amelybe a Vallás- és Közoktatásügyi Minisztérium (VKM) elnöki osztályán dolgozó iskolaigazgató került. Mindkét bulvárlap nagy teret szentelt a bünesetnek, többször visszatértek rá a hónapok során: „Ottó Károly iskolaigazgató megvesztegetési ügyében több kihallgatást tartanak”. A kinevezésért „5000 pengőt kért Surányi Mária tanítótól” (Az Est, 1930.07.27., 4. o.). Az ügy súlyosságára tekintettel a táblabíróság letartóztatásban tartotta az igazgatót, „Ottó Károly sírva fakadt" a döntés hallatán (8 Órai Ujság, 1930.07.29., 6. o.).

A vesztegetési ügy nem egyedi, hiszen a fővárosban Bednárcz Róbert pápai prelátussal, a Keresztény Községi Párt képviselőjével szemben is vizsgálatot folytattak. A gyanú szerint 1500 pengőért egy fővárosi tanítónőt, Kiss Etelt állami tanítói álláshoz juttatta volna a politikai kapcsolatai segítségével (Az Est, 1934.05.03.).

Természetesen a büncselekmények megítélése egyértelmű. A gazdasági válság elhúzódása és mélyülése a korrupciós összegek „inflálódásán” keresztül is nyomon követhető, illetve a tanítók, tanítónők anyagi ellehetetlenülése és kiszolgáltatottsága is jól érzékelhető. Az utóbbira sajnos jó példa az az eset, amikor a „korgó gyomor” vezette a bün útjára azt a tanítónőt, aki kilátástalan anyagi helyzetében megzsarolta Tabódy Tibor országgyülési képviselöt annak érdekében, hogy szerezzen számára állást (8 Órai Ujság, 1934).

$\mathrm{Az}$ Est vezércikkében is foglalkozott a vesztegetési üggyel (Ottó Károly), a tanítóság helyzetével, és egyértelmüen ok-okozati összefüggést vélt találni az egyre növekvő, szinte mindent átható, még az oktatásba is beszivárgó korrupció és a kormányzat tevékenysége között.

\section{Tanítók egzisztenciális viszonyai}

A világválság eszkalálódása miatt a bulvárlapok tudósításaiban is egyre gyakrabban jelentek meg a tanítói fizetésekkel kapcsolatos tartalmak: „Állami Tanítók Országos Egyesülete kéri a VKM miniszterét, hogy az állami tanítók fizetését semmiképpen se csökkentsék, mert így is a megélhetési 
minimum alatt keresnek” (Az Est, 1930.11.26., 7. o.). „A fővárosi tanárok és tanítók a fizetésredukció ellen. A memorandumban azt kívánják bizonyítani, hogy a fizetéseket nem lehet leszállítani, mert a „mostani fizetések a békebelieknek úgyis csak $60-70$ százalékát teszik ki” (8 Órai Ujság, 1931.8.27., 5. o.). A hónapról hónapra romló gazdasági helyzetet jól mutatja, hogy 1931 szeptemberében a miniszteri rendelet „a nem állami elemi iskolai tanítók, óvónők, [...] vagy helyettes tanítók és óvónők fizetésének kiegészítésére szolgáló államsegély összegét szeptember elsejétől kezdődőleg tíz százalékkal redukálja" (8 Órai Ujság, 1931.9.30., 5. o.).

A legnagyobb anyagi nehézséggel főleg a felekezeti tanítók szembesültek: ,a Pest megyei felekezeti tanítók nem kaptak fizetést" (Az Est, 1932.10.24., 4. o.). De nemcsak a fóvárosközeli területeken szenvedtek a fizetési nehézségek miatt a felekezeti tanítók, hanem más országrészek is elmaradtak a fizetésekkel: „Számos egyházközségben tíz hónapja egyetlen fillér fizetést sem kaptak a tanítók. A legtöbb iskolát füteni sem tudják, a tanítók dideregve télikabátban tanítanak”. „,...] a tanítók [...] a szó teljes értelmében éheznek" - olvasható Az Est cikkében (1932.11.27., 8. o.). Az áldatlan állapotokat jelzi a felekezeti tanítók éhínséggel határos állapota, melyről szintén Az Est híradásai számoltak be: „A szoboszlói református egyház 28 tanítója éhínséggel küzd”; „Éheznek és fáznak a hajdúsági felekezeti tanítók" (1933.9.23., 15. o.).

A tanyai tanítók, akik alapvetően felekezeti fenntartású intézményekben tanítanak, anyagi nehézségeit fokozza, hogy járandóságaik egy részét terményben kapják, de az államilag meghatározott beszámítási ár és a valós piaci ár között jelentős lett a különbség: A 8 Órai Ujság tudósítása szerint „a képviselöház legutóbb foglalkozott azoknak a tanítóknak [...] a sérelmével, akik járandóságukat természetben, föleg búzában kapják" (1930.12.23., 4. o.).

Az Estben közölt egyik panaszos levélből szerezhetünk pontos információkat a 4000 tanítót érintő természetbeni juttatás problematikájáról: „az állam által beszámított gabonaáron (27.80 pengő) valójában nem veszik meg tőlünk a gabonát csak 19 pengőért” (1930.12.14., 8. o.). A gazdasági válság elhúzódása miatt állandósult a fizetésképtelenség, mely a néptanítói praxist is igen súlyosan érintette, ezt Gömbös Gyula és Hóman Bálint is érzékelte. A tanítógyülés háromezer fös hallgatósága előtt fogalmazták meg: „Korgó gyomorral nem lehet tanítani!” (Az Est, 1932.12.30., 4. o.)

A romló gazdasági helyzet kihatással volt az oktatás infrastruktúrájára is, és ennek okán egyre több cikk központi témája lett az áldatlan körülmények, az iskolai helyzet, a munkakörülmények bemutatása. A válság eszkalálódását jól jelzi, hogy a bérfizetés nehézségein túl már a felekezeti fenntartók oktatási intézményükkel kapcsolatos korábbi ragaszkodása is megkopott: „Az egyházközségek mindent elkövetnek, hogy szabaduljanak az iskolafenntartás gondja alól, mert nem bírjak a terheket. A városok sem tudnak fizetni, mert nincsen pénzük" (Az Est, 1932.11.17., 8. o.). Az Est tudósítása szerint a fővárosi tanügyi bizottság ülésén is a tervezett megvonások miatt konfrontálódtak a résztvevők: „Ne takarékoskodjanak az iskola rovására” - a főváros gazdasági helyzete miatt újabb megvonások" várhatók (1930.9.20., 2. o.).

A tanyai tanítók anyagi helyzete olyannyira kilátástalannak tünt, hogy már 1930 öszén megalakult a Tanyai Tanítók Országos Egyesülete. Az igen nehéz körülmények miatt körükben a tanítói mobilizáció kiugróan magas volt, éppen ezért felmerült a helyhez kötött müködési pótlék juttatása részükre, de a válság miatt ennek megvalósítása elmaradt. Szintén a munka nehézsége miatt jelezték az állami elemi iskolák vezetői, hogy a tanítók vidéki kinevezésénél vegyék figyelembe, hogy nagyon nehéz munkakörülmények várnak a tanítókra, tehát föleg férfiakat vegyen állásba a fenntartó.

1932-re a válság miatt a munkanélküliség olyan szintre emelkedett, hogy már a diplomás munkanélküliség is komoly gondot okozott, és ennek egyik újabb vetülete lett az üres állásokra benyújtott pályázatok elbírálásnak problémája. A diplomás munkanélküliség, mely érintette a tanítókat is, olyan élethelyzeteket is eredményezett, amikor a végzettségi szint alatti munkakörre nyújtott be pályázatot tanító.: „Az egyik vármegyei útmesteri állásra pályázatot hirdettek. A nagyon szerény javadalmazással járó állásra száz és száz ember adta be pályázatát. A 240 pályázó közül 22- 
en doktorok, de pályázott az útmesteri posztra húsz tanító is, sőt egy okleveles mérnök is" (Az Est, 1932.4.3., 7. o.). A munkanélküliség emelkedése miatt Az Est cikke szerint (1931) az álláshalmozók ellen fordult a közhangulat, köztük olyanok ellen, akik egy kisebb közösség megbecsült tagjai voltak: „nő az álláshalmozók ellen az országos mozgalom - tanító, akinek háza, szőlőbirtoka van és egyben gazdasági egyesületi titkár is" (2. o.).

Az egyetemi képzés túltermelése erre az időszakra egyértelművé vált. Szinte alig tudtak munkát találni a végzettek. Az elhelyezkedni képtelen réteg radikalizálódásának csökkentése érdekében kormányzati irányítással alakult meg az Állástalan Diplomások Országos Bizottsága (ÁDOB), melynek feladata volt, hogy az állami rendszerben kisegítői munkakörökhöz juttassák minimális bérért az értelmiségi munkanélkülieket (Kövér és Gyáni, 2006).

Főleg Az Est, de a 8 Órai Ujság is előszeretettel közölt olyan külföldi híreket, melyek egy része érintette az európai és az amerikai tanítók életkörülményeit. A következő cikk komoly párhuzamot mutatott a hazai helyzettel: „Csikágó 5 ezer tanítója hónapok óta nem kapott fizetést” (Az Est, 1933.4.29., 7. o.), de Írország és Skócia gazdasági helyzete is nehezen birkózott meg közoktatás finanszírozásával: „tízezer ír tanító ma reggel sztrájkba lépett” (1933.4.27., 2. o.), valamint „leszállítják ötezer glasgowi tanító fizetését” (8 Órai Ujság, 1931.2.28., 5. o.). A Bukarestben zajló tüntetésről és utózöngéjéről már egy kevésbé óhajtott jövőképet vázolt a 8 Órai Ujság: „,Szuronyos csendőrök és rendőrök verték szét hatezer román tanító gyülését. Küldöttséget kívántak meneszteni „Jorga miniszterelnökhöz azzal a kérelemmel, hogy az iskolák számának tervbe vett redukciójánál tanítók ne veszítsék el állásukat" (1931.7.18., 4. o.).

\section{Iskolaegészségügy}

Az Est és a 8 OOrai Ujság cikkeinek elemzése során került felszínre a tanítók, az iskola, a diákok egészségügyi helyzete. Egy olyan világ tárult fel előttünk, mely ismerve a gazdasági válság hatásait, talán nem meglepő, de mindenképpen megdöbbentő.

A népiskolai fejlesztések eredményeképpen, az 1926. évi VII. törvénycikk rendelkezései nyomán néhány év alatt több ezer tanterem és tanítói lakás épült meg (Szabó, 2008). Bár az építkezések során ügyeltek arra, hogy a lehető legjobb minőségben készüljenek el az új épületek, épületrészek, a felújítások, de főleg a tanyai területeken, illetve a külterületeken felépített egy-két tantermes iskolaépületek minősége - a gyors építési tempó és a már korábban is hiányos infrastruktúra miatt - kifejezetten problémás volt. Az elkészült és átadott kisiskolák higiénés adottságai (víz- és csatornahálózat és a fütési rendszer hiányosságai) előrevetítették a megszaporodó egészségügyi problémákat. A fertőzések gyors terjedését fokozta a relatíve magas osztálylétszám is, mely főleg a tanyai iskolák esetében volt kiugróan magas (Benisch, 1930; Pornói. é.n.; Romsics, 2010).

Mindkét bulvárlap beszámol arról, hogy „2200 trachomás beteg van Szegeden. Felmerült, hogy tanítókat okítanának ki a megelőzés, kezelés területére" (Az Est, 1930.8.13., 8. o.). Az elhúzódó ügyre végül Dr. Somogyi Szilveszter polgármester tett pontot a válaszában: ,idegenkedik attól a megoldási lehetőségtől, hogy a tanítók kezeljék a betegeket. Ugyanis a nyolcvanhat tanító kioktatása költséges lenne" (8 Órai Ujság, 1931.7.14., 4. o.).

1930 októberében a soroksári „központi elemi iskola tanulói között diftériás megbetegedések történtek. Huszonnyolc beteg közül öt meghalt. Az iskolát bezárták" (8 Órai Ujság, 1931.10.21., 14. o.).

1931 februárjában és márciusában influenzajárvány és kanyaró miatt zártak be iskolákat. Ugyanezen év novemberében „különösen a skarlát-betegek száma szaporodott. A IX. kerületi Ernő uccai iskola első három osztályában az utóbbi napokban 25 gyerek betegedett meg skarlátban, úgyhogy a kerületi tisztiorvos elrendelte a három osztály bezárását” (Az Est, 1931.11.11., 8. o.).

Magyarországon 1931-ben súlyos gyermekparalízis-járvány alakult ki, melynek következtében 
Debrecenben „dr. Vásáry polgármester engedélyt kért a kultuszminisztertől az iskolák megnyitásának elhalasztására" (8 Órai Ujság, 1931.9.5., 4. o.). Az 1931-es magyarországi gyermekparalízis-járvány következtében körülbelül 5000 ember - föleg gyermek - vesztette életét (Gy. Dobos, 2014).

Székesfehérvárott és Budapesten is az 1932-es év iskolabezárásokkal kezdődött az influenzajárvány miatt. Szolnokon pedig torokgyík miatti fertőzés okozott járványt: ,a Konstantin elemi iskola tanulói között diftériás megbetegedések fordultak elö, ezért az iskolát bezárták" (Az Est, 1932.10.4., 7. o.). A fertőző megbetegedések mind a nagyvárosi, mind a külterületi, tanyai közegben megjelentek, és komolyan veszélyeztették nemcsak a gyermekek, hanem a velük közvetlen kapcsolatba kerülő tanítók, tanárok egészségét is. Nem véletlen, hogy a szegedi nagy létszámú trachomás megbetegedések idején - bár felmerült a pedagógus kar beemelése a megelözésbe, a kezelésbe - a tanítók határozottan elzárkóztak az orvos-helyettesítő szereptöl.

Az Est számolt be arról (1933), hogy az 1933-as év is a korábbihoz hasonlóan kezdődött: „Debrecen csaknem valamennyi iskoláját bezárták a nagymérvü influenzajárvány miatt. Az elemi iskolák, óvó-, tanítóképző intézetek és egyéb iskolák után a napokban a Dóczi- és Svetitsintézeteket zárták be, most pedig a református fögimnázium és iskolájának bezárásáról döntöttek" (1933.2.26., 9. o.).

Magyarország iskola-egészségügyi helyzete nem vonatkoztatható el az ország egészségügyi állapotától, de ezen túlmenően is vannak olyan, az oktatás müködési rendjéből fakadó specifikus adottságok, melyek rontottak az elemi iskolában tanuló diákok és tanítóik általános egészségügyi helyzetén. Ezek egyike a Klebelsberg Kuno által elképzelt és megvalósított, föleg a tanyai népiskola-építési hullám jellegéből fakadt: az egy-két tantermes iskolák építése főleg az egyébként is gyenge egészségügyi-szociális-infrastrukturális adottságokkal rendelkező tanyai területeken zajlottak, ahol az ott élők egyébként is alapvető ellátásbeli problémákkal (pl. orvosi) küzdöttek. Az iskolaépületek is gyenge minőségben épültek meg, továbbá a tanyai, falusi területek közműellátottsága, valamint köz- és vasúti megközelíthetősége alacsony nívójú volt, mely nehezítette például a hatékony orvosi ellátást. Ezt tetézte az osztálylétszámok igen magas száma is, mely szintén föleg a tanyai iskolai közegben volt jellemző, ahol ráadásul az osztatlan képzésből fakadóan még magasabb diáklétszámmal müködtek az iskolák: 40-50 diák tartózkodott a tanteremben egyszerre, ráadásul több korosztály egyszerre.

Kevésbé közismert tény, hogy főleg az Alföldön, ahol a szórványtelepülések jellegéböl fakadóan az iskolaköteles gyermekek száma nem érte el a kívánt nagyságot, ott nem épültek iskolák, így az érintett kisdiákok távolabbi településekre voltak kénytelen ingázni, legtöbbször gyalogosan. Télen, esőben, akár zord időjárási körülmények között is. Ez a helyzet jelentősen befolyásolta egészségügyi állapotukat, mely kihatott szűkebb környezetükre, vizsgálatunk szempontjából a tanítóikra is.

Az 1930-31-es tanévben az iskolaköteles diákok 18 százaléka járt teljesen osztatlan, tehát nagy létszámú osztályba (Romsics, 2010). Ez a helyzet nagy gondot jelentett a cseppfertőzéses (influenza, kanyaró, diftéria) megbetegedések időszakában. Már az 1930-as években a politikai diskurzus részévé vált a helyzet rendezése, hiszen a fővárosi tanügyi bizottság ülésén hangzott el: „Nem lehet tovább halasztani az iskolaegészségügyi intézmények megszervezését” (Az Est, 1930.9.20., 2. o).

\section{Sérült, fogyatékkal élő gyermekekkel foglalkozó tanítók}

A jelenleg elfogadott szak- és köznyelvi terminológiákkal ellentétben a 30-as évek újságírói és ezáltal feltételezhetően köznyelvi szókincse az érinttet témakörben - mai füllel - kissé ridegnek számít. A fellelt, egyébként kis számú újságcikkek nyelvezete mai felfogásunk szerint nyers, sértő: nyomorék, béna, gyöngeelméjü, félkegyelmü.

A gyermekvédelmi-gyógypedagógiai professzió szakmásodásának kezdete az Eötvös-féle népiskolai törvénytől datálható. Természetesen nem önálló pedagógiai szakmacsoportként kezdték meg a tevékenységüket, hanem a tanítói szakma mellékágaként. A századfordulón sem jelent meg 
önálló pedagógiai szakterületként. Ettől függetlenül a tanítói szakma fejlődése révén előtérbe kerültek azon gyermekekkel kapcsolatos pedagógia feladatok, melyek a beilleszkedni nem tudó diákok előmenetelét segítették (Hegedüs, 2016). A társadalmi kitaszítottság érződik az orgánumok sérült gyermekekkel és oktatásukkal kapcsolatos témáin, hiszen a cikkek mennyisége egyértelmüen jelzi számunkra a téma tabusítását. A vizsgált időszakban elvétve, illetve szinte alig találunk a sérültek pedagógiájával, sérült gyermekek tanításával foglalkozó tartalmakat. Viszont amennyiben megjelenik a témával foglalkozó riport, tudósítás, a szakemberek heroizálása is tetten érhető a publikációkban.

Az Est 1930. július 23-án publikált cikke, melynek szerzője Révész Béla, részletesen és nagy szakmai alázattal számol be arról az elhivatott tevékenységről, mely az értelmi fogyatékos gyermekek fejlesztésekor zajlik: „A tanárok tudják, hogy fogyatékos gyerekekkel állanak szemben és a pedagógiájuk is olyan jellegü, hogy szüntelen ügyelik a növendékek kóros hajlandóságait és a praktikusság szerint váltogatják a tanítás módjait" (10. o.). A cikk hangsúlyozza a pedagógusok szaktudását, mely nélkül sikertelenségre lenne ítélve a tevékenységük:" ismerik a gócpontokat, ahonnan az olvasásnak, írásnak képessége kiindul, és ahonnan nem indul; ott vagy tompultság vagy bénultság akadályozza a nevelés kísérleteit. A tanárok itt valamennyire orvosok is. Speciálisan képzettek és a pedagógián kívül nagyon kell tudniuk az ember testi, szellemi konstrukciójának törvényeit" (10. o.). A szerző állítása szerint Magyarországon 10.000 családot érint a sérült gyermek nevelése. Révész Béla következő cikkében bemutatja a sérült, föleg szellemileg sérült gyermekekkel foglalkozó Állami Gyógypedagógiai Kórtani és Gyógypedagógiai Laboratórium tevékenységét.

1931 júniusában a 8 Órai Ujság számolt be a nyomorék gyermekek napjának utcai gyüjtéséről. A Nyomorék Gyermekek Országos Otthona (Budapest, Mexikói út 63.) az országban egyedülálló intézményként müködött. Az intézmény orvosi részlege, elemi iskolája, tanonciskolája lehetővé tette a komplex fejlesztést, rehabilitációt. A 8 Órai Ujság rövid cikke (1930. szeptember 5.) az intézet mühelyeiben termelt, gyártott termékek megvásárlására kéri fel az újságolvasókat, ezzel is támogatva a képzést.

Az Európában az elsők között 1825-ben megalakuló Vakok Intézetét bemutató hosszabb terjedelmü cikk jelent meg Az Estben 1933. június 25-én. Herodek Károly nemzetközileg elismert gyógypedagógus mutatja be az intézeti munkát, a pedagógusok mindennapjait.

Szintén egy kiemelkedő gyógypedagógus, dr. Náray Szabó Sándor által alapított Kisegítő Iskola bemutatása történik 1934. november 30-ai cikkben, melyben visszaköszön az a koncepció, mely a Vakok Intézetében zajló képzésben is prioritásként jelent meg, miszerint a munkaerőpiacon elhelyezkedni képes tanulókat képezzenek: „A fiúk az iskola elvégzése után iparostanoncoknak mennek, a leánykák gyárakban, mühelyekben, varrodákban próbálnak elhelyezkedni” (7. o.).

\section{Tanítók és a szakmai munka}

Az 1920-as évek második felétől kezdve Kornis Gyula vezetésével a neveléstudomány akadémiai folyóirata, a Magyar Paedagógia egyre intenzívebben vállalta fel a gyermektanulmány, a reformpedagógia szakmai alapvetéseinek közlését. A publikációk először a középiskolai tanárok, majd a praxispedagógia képviselőnek nézetét befolyásolhatták (Németh, 2014), így a hazai praxisban is egyre inkább előtérbe kerültek a gyerekközpontú, a gyermeki adottságokra, a motiváció fontosságára építő új pedagógiai irányzatok. A magas tandíjaik miatt föleg a polgári középosztály gyermekei számára elérhető reformiskolák, bár nem jelentős számban voltak jelen a hazai oktatási kínálatban, egyre erőteljesebb hatást gyakoroltak - a külföldi pedagógiai eredményekkel megerősítve - a hazai pedagógia elméleti és gyakorlati szakembereire. A tudományos kánonban, majd a praxispedagógiában való egyre aktívabb megjelenés a bulvárlapok szerkesztőire is hatást gyakorolt: egyre gyakrabban adtak teret a reformpedagógiával foglalkozó tartalmaknak. A két vizsgált bulvárlapban is megjelentek a pedagógia újdonságairól, a reformpedagógia képviselőiről szóló híradások, tudósítások, kiemelve a tanítói ismeretek egyre nagyobb értékét. A cikkek 
szemléletformáló hatással is bírtak.

Az Est a nyugat-európai oktatási-nevelési szemlélet változásáról cikkezett: „Franciaországban komoly hagyományai vannak a gyermeknevelés témakörének, ha a gyerek nem figyel, akkor beteg, rossz a szeme, a füle vagy a tanítója gyenge" - reflektál a cikk arra, hogy változóban van az a szemlélet, hogy mindenről a diák tehet.

1926 őszén Magyarországon tett látogatást a népszerüségnek örvendő Rabindranáth Tagore indiai költő, irodalmár, gondolkodó, iskolaalapító, akinek a 20 -as évek második felében több könyvét is magyarra fordították. Az Est tudósítása beszámol arról (1930), hogy az indiai Nobeldíjas a new-yorki előadásán megosztotta a hallgatósággal gyermekkori iskolai kudarcélményeit: "Ha bejött a tanár úr, fel kellett állni, halálos csendben kellett végig hallgatni azt, amit mondott. [...] hallgatni kellett, pedig kérdezni szerettünk volna" (8. o.).

A reformpedagógia recepciójára jó példa, hogy társadalmi felvilágosítás fontosságát előtérbe helyezve előadássorozatot szervezett a „Magyar Gyermektanulmányi és Gyakorlati Lélektani Társaság Imre Sándor dr. vezetésével” prominens előadók sorát felsorakoztatva: „Weszely Ödön dr. egyetemi tanár, Drozdy Gyula tanár, Éber Rezső tanár, Dienes Valéria dr. mozgásművészeti iskolai igazgató" (8 Órai Ujság, 1931.11.15., 4. o.).

Szintén a reformpedagógia recepciós folyamatának szerves részeként értelmezhető, hogy Maria Montessori személyes jelenlétével tisztelte meg a hazai érdeklődőket, és „,szervezetéről ma délután tart előadást az Akadémia üléstermében, mint a Magyar Pedagógiai Társaság vendége" (8 Órai Ujság, 1930.12.21., 7. o.).

A pedagógiai tartalmak hírértékét jelzi, hogy egy bulvárlap cikket szentelt annak, hogy a Magyar Gyermektanulmányi Társaság Nagy László halálát követően úgy döntött, „a magyar gyermektanulmányi mozgalom megindítójának emlékét megörökíti” (8 Órai Ujság, 1932.02.18., 2.o.).

A tanítóság szakmai munkájának értékelése során visszatérő elem volt, hogy az újságolvasókat tájékoztatták a pedagógusi szakmát övező infrastrukturális adottságokról. Az oktatás minőségének visszatérő kritikái ugyanis gyakran az osztálylétszámok magas számában keresték és találták meg a bajok forrását. A főváros tanügyi bizottsága is problémaként tekintett a magas budapesti osztálylétszámokra: „Lehetetlenség az, hogy túlzsúfolt osztályok legyenek, 48-50 gyerek is van egy osztályban, holott eredményes tanítást legfeljebb 30-35 gyereknél lehet elérni” (Az Est, 1930.9.20., 2. o.).

A létszámgondokon túl szociokulturális hátterü a szegedi tanítók azon problémája, hogy olyan családok gyermekeit oktatták, akik mákkal nyugtatták a síró-rívó, hisztiző gyermekeiket. Az Est tudósítása szerint „a tanyai szülők tejbe vagy vízbe fött mákfejet adnak be síró kisgyermekeiknek” (1930.2.12., 4. o.). A tanítói vélekedések szerint a családokban a mákkal kábított kisgyermekek teljesítménye oly mértékben leromlik, hogy „az iskolába kerülő tanyai gyermekek nagyrésze minimális értelmi képességekkel rendelkezik" (4. o.). A szegedi tanfelügyelő körrendeletben hívta fel az érintett tanyai iskolák igazgatóinak figyelmét a szülők által alkalmazott jóhiszemü, de igen káros családi szokásra, továbbá kérte az oktatógárda tagjainak segítségét a felvilágosító munka terén.

\section{Tanítóság által alkalmazott nevelési-fegyelmezési módszerek kritikája}

Az oktató-nevelő munka módszertanának kritikája leginkább a fegyelmezés problematikáján keresztül jelent meg a bulvárlapok olvasóközönsége számára. A pedagógiai fegyelmezés eszközének tartott testi fenyítés alkalmazása - bár a konkrét esetek teljes hátterét nem ismerjük több okra is visszavezethető. Az egyik a népiskolai tanítók végzettségéből fakad: az érettségivel nem rendelkező tanítók gyakran szembesültek középiskolai vagy magasabb végzettséggel rendelkező szülök kritikájával, mely egynémely esetben tekintélyromboló is lehetett (Nagy, 2002). Szintén a presztízsproblémák okai közé sorolható, hogy a Horthy-korszak társadalmi szerkezetében a tanítók nem tartoztak a középosztályhoz, társadalmi elismertségük alacsony volt. Ehhez társult 
még a tanítói szakma feminizálódása is, mely szintén erodálhatta szakmai reputációjukat a kor társadalmi szemlélete miatt (Kövér és Gyáni, 2006). Nem utolsó sorban az I. világháborút követően kormányzati cselekvéssé vált a tartalékos tisztek tanítói állásba történő helyezése, ezáltal joggal feltételezhetjük, hogy az így tanítói praxisba kerülők esetében szaktudásbeli hiányosságok mutatkoztak. Ugyanis erre az időszakra a néptanítói szaktudás már alapvetően tartalmazta - többek között - a gyermeki jogokkal kapcsolatos ismereteket is (Baska, 2011). Nem utolsó sorban a gazdasági válság miatt a gyakran elmaradozó, ki nem fizetett bérek kikezdték egynémely tanító türelmét.

„Furcsa dolgok az Angol uccai elemiben; Büki Béla tanító megverte az egyik osztályába járó diákot. Elnézést kért, de a cselekmény folytatódott más gyermekkel” (Az Est, 1930.3.30., 4. o.). A 8 Órai Ujságban is jelent meg iskolai testi fenyítésről szóló hír: „Nemes Gyula gyermekét a tanító arcul ütötte. Az eset megismétlödött, mire (az apa) újból levelet írt az igazgatóhoz és ebben többek között azt írta, hogy a tanító csak így tud fegyelmet tartani” (1930.11.8., 4. o.).

Az iskolai testi fenyítések társadalmi elfogadottságának és büntetőjogi megítélésének változását jól mutatja a következő eset, mely a 8 Órai Ujságban jelent meg (1931). Már a cikk címe is állásfoglalás: „A pofozás nem tartozhat a tanítás eszközei közé”. Egyébként a tettlegességgel vádolt tanítók sok esetben rágalmazásért feljelentették az őket hírbe hozó szülőket. Az előző esetben végül „pénzbüntetésre ítélték a tanítót, mert megverte a tanítványát.” Az ügy jogi érdekessége, hogy a védöügyvéd a tárgyalás során, ,arra hivatkozott, hogy a tanítót megilleti a házi fegyelmi jog és így a cselekmény nem büntethető” (5. o.). Szintén tanító által elkövetett bántalmazás: a „kántortanitó az iskolában Tunkl kisfiát súlyosan bántalmazta, többször arcul ütötte. A kántortanító rágalmazás miatt ekkor is feljelentette az édesapát. „A törvényszék a bántalmazás tényét lényegileg igazoltnak vette és megállapította a bíróság, hogy a gazdálkodó igazat mondott, amikor a tanító eljárását szóvá tette" (8 Órai Ujság, 1931.3.6., 6. o.).

Nemcsak férfi tanítók, hanem tanítónők is alkalmazták a testi fenyítést: „vádat emelt az ügyészség Barta Lajosné, hajduhadházi elemi iskolai tanítónő ellen, mert Takács Irén nevü 10 éves növendékét 63 nádpálcányi ütéssel olyan súlyosan bántalmazta, hogy sérüléseit hosszabb ideig kellett gyógykezelni” (Az Est, 1932.10.21., 8. o.). Szintén egy tanítónő által alkalmazott testi fenyítés került a fókuszba egy újabb terjedelmes cikkben: „kékre-zöldre vert egy hétéves gyereket a Hernád uccai elemi egyik tanítónője”. A cikk állítása: „mindenki szerint volt verés! Lakits Aranka tanító elismeri a pálcázást, de a figyelmetlen tanuló megérdemli, és egyébként is vékony nadrág volt rajta" (Az Est, 1932.10.28., 3. o.).

Az Est lapjain is visszatérő téma volt a szakmailag-emberileg vállalhatatlan tanítókról szóló cikkek sorozata. A pedagógiai professzió gyakorlójának alkalmatlanságát mutatta be az a cikk, amely egy szélsőségesen agresszív tanító esetét eleveníti fel: „Lábuknál fogva akasztotta fel tanítványait a kiskunmajsai tanító. A fegyelmi bizonyítottnak látja [...] gyerekeket kutyájával maratta meg, kikötötte, lábuknál fogva akasztotta fel tanítványait” (Az Est, 1933.6.10., 6. o.). Az inkriminált tanítók által elkövetett cselekedetek - bár pedagógiai problémának látszanak - gyakran a büncselekmény kategóriáját súrolják, illetve meg is valósítják azt: „Schiffer Hugó szajoli tanító felbőszült azon, hogy osztályában a gyerekek lármáztak és egy vonalzóval véresre verte Szekeres János 10 éves tanulót. A szülők feljelentésére könnyü testi sértés címén megindult az eljárás a tanító ellen" (Az Est, 1934.5.26., 3. o.).

\section{Kultúrfölény, nemzetnevelés, szakmai felelősség}

Gr. Klebelsberg Kuno kultúrfölény-programja, illetve Hóman Bálint nemzetnevelés eszménye visszaköszönt némely cikkben, jelezve a pedagógusok elköteleződését a szakma, a hivatás iránt.

Az Est 1930. április 10-án publikált vezércikkében áll ki az iskolaépítési koncepció mellett és egyben a minisztert is támogatásáról biztosítja. Szintén a miniszter nézeteinek elfogadottságát jelezte azon cikk, amelyben hangsúlyosan szerepelt a kormányzati ellenzék elismerő megnyilvánulása a kultuszminiszter felé. 
A tanítók elhivatottságára bizarr módon mutat rá Az Est 1930. december 6-ai tudósítása: „Tanítás közben meghalt a tanító - Bellák Jenő tanító már reggel panaszkodott kollégáinak, hogy fáj a mellkasa”. Az igazgató haza akarta küldeni, de Bellák azt felelte: „A kötelesség mindennél előbbre való!" (16. o.) Szintén egy korábban már bemutatott Az Est-tudósítás újabb aspektusa is említést érdemel: ,[...] öngyilkos lett a pásztói tanítónő. Tegnap délután még rendben elvégezte munkáját, megtartotta óráját az iskolában [...]” majd otthonában öngyilkos lett (1930.7.27., 9. o.).

Egy rövid terjedelmü hír szól a tanítók helyes megszólításról: „a tanítónő köszöntése: kezit csókolom helyett: Szebb jövőt!" A tanítói professzió követendő céljait vázolta a Budapesti Tanító Testület közgyülésén elhangzott eszmefuttatás, melynek vezérgondolata: „a pedagógus feladatai vallásosságra, szerénységre nevelés, kötelességtudó, és életrevaló ember képzése (...).” Az oktatási paradigmaváltás egyértelmü: az írástudás elsődlegességét felváltotta a kötelességtudás princípiuma.

\section{Konklúzió}

A jelentős olvasótáborral rendelkező Az Est és a 8 Órai Ujság cikkei tematizálták a közbeszédet, hiszen az írott sajtó az 1930-as évek hajnalán jelentős bázissal rendelkező tömegmédiumként volt jelen a tömegtájékoztatásban. A vizsgált szövegek a tantóság szakmai és civil életének egy-egy, gyakran igen fontos aspektusát mutatták meg. A feltárt motívumok egyértelmüen a tanítókról szóló diskurzusok részei voltak.

Az 1930-as évek fordulóján a tanítói praxisban tevékenykedő tanítók és tanítónők nehézségei, kihívásokkal teli élete egyértelmüen megjelenik a vizsgált bulvárlapok hasábjain. Az állami és a felekezeti tanítókat érintő bérfizetési nehézségek, több hónapnyi elmaradások mind Az Estben, mind a 8 Órai Ujságban jelentős teret kaptak. A kutatás rugalmassága során kerültek felszínre olyan tartalmak, melyek a tanítók munkakörülményeiről szóló ismereteinket árnyalták. Az oktatásban tapasztalható egészségügyi-higiénés körülmények komoly életvezetési problémákat okoztak a tanítóság körében. Az influenzajárványok, kanyaró, torokgyík és az ország első gyermekbénulásos járványa is a vizsgált időszakra esett. Felmerült a tanítók integrálása az iskola-egészségügy normalizálásába, de a szakpolitikai törekvéseknek a szegedi tanítói professzió ellenállt.

Az újságolvasók számára az oktató-nevelő munka explicit megjelenése a tanítói fegyelmezés körébe tartozó testi fenyítések alkalmazása, azok társadalmi és munkáltatói megítélése, valamint büntetőjogi következményei voltak: terjedelmes riportokban, tudósításokban számoltak be a kirívó esetekröl.

Záró gondolatként: joggal vélelmezhetjük az időszak gazdaság- és társadalompolitikai körülményeit ismerve, komoly elhivatottság, szakmaszeretet szükségeltetett a pályán maradáshoz.

A vizsgált időszak bulvárlapjaiban feltárt számos párhuzam a mi időszakunkra vonatkoztatva elgondolkodtató és tanulságos.

\section{Irodalom}

Baska, G. (2011). Iskola, gyermek és tanitó ideál a 19. 20. század fordulóján. Budapest: Gondolat Kiadó. Letöltés: 2017. december 21., Web: http://mek.oszk.hu/14700/14797/14797.pdf

Benisch, A. (1930). Az elemi népoktatásunk fejlődése 1919 óta. Néptanitók Lapja 25-32. szám.Web:https://adtplus.arcanum.hu/hu/view/NeptanitokLapja1930/?pg=625\&layout=s\&quer $\mathrm{y}=$ benisch. Letöltés ideje: 2018.02.23.

Buzinkay, G. (1997). Bulvárlapok a pesti utcán. (Gyáni, G. Szerk.) Budapesti Negyed, 5. évf. Letöltés: 2018. május 20, Web: http://epa.oszk.hu/00000/00003/00014/buzinkay.htm

Buzinkay, G. (2009). Hírharang, vezércikk, szenzációs riport - Magyar sajtótörténeti antológia 1780-1956 . (Buzinkay, G., Szerk.) Budapest: Corvina Kiadó.

Buzinkay, G. (2016). A magyar sajtó és újságírás története a kezdetektöl a rendszerváltásig. Budapest: Wolters Kluwer Kft. 
Géring, Zs. (2014). Tartalomelemzés a virtuális és a valós világ határán. Kultúra és Közösség, 5. évf. 1. szám 9-24. Letöltés: 2018. április 29., Web: http://www.kulturaeskozosseg.hu/pdf/2014/1/03.pdf

Gy. Dobos, M. (2014). A járványos gyermekbénulás problémájára adott társadalompoltikai válaszok Magyarországon 1948-tól. Budapest. Letöltés: 2018. március 18., Web: http://www.meosz.hu/wpcontent/uploads/2016/03/20160413_heine_medin_tarsadalompolitika_ gy_dobos_mariann.pdf

Hegedūs, J. (2016). A gyermekvédelmi szakma professzionalizálódása. In A. Zsolnai, \& L. Kasik (Szerk.), Szegedi Tudományegyetem, (old.: 81). Szeged. Web: http://www.edu.uszeged.hu/onk2016/download/ONK_2016_program_es_absztraktkotet.pdf, Letöltés: 2018. május 23.,

Klein, T. (2015). A sajtószabadság története Magyarországon 1914-1989 (2015. kiad.). (V. Paál, Szerk.) Budapest: Wolters Kluwer.

Lipták, D. (1997). A családi lapoktól a társasági lapokig. (Gyáni, G., Szerk.) Budapesti Negyed, 5. évf. Letöltés: 2018. február 28., Web: http://epa.oszk.hu/00000/00003/00014/liptak.htm

Nagy, P. T. (2002). A magyar oktatástörténet szociológiai narratívája. In memoriam Pierre Bourdieu. Szociológiai Szemle, 12, 24-42. Letöltés: 2018. május 20., Web: http://www.szociologia.hu/dynamic/0203nagy.htm

Németh, A. (2014). A magyar neveléstudomány fejlödése. Nemzetközi tudományfejlödés és recepciós hatások, egyetemi tudománnyá válás, középiskolai tanárképzés. Budapest: Gondolat Kiadó.

Palló, G. (2007). Klebelsberg Kuno: politkus kultuszminiszter. Magyar Tudomány, 12, 1619. Letöltés: 2018. április 23., Web: http://www.matud.iif.hu/07dec/17.html

Pornói, I. (dátum nélk.). A népiskola a két világháború közötti kultúpolitikábanWeb: http://www.nyf.hu/fakultas/szocped/publikaciok/NepoktatasaIIvhb.doc, Letöltés: 2018. március 17.

Pukánszky, B., \& Németh, A. (2001). Neveléstörténet. Letöltés: 2018. március 16., Web: http://magyar-irodalom.elte.hu/nevelestortenet/index.html\#11

Romsics, I. (1996). Bethlen István miniszterelnöksége. Rubiconline, 10, 15.,Web:http://www.rubicon.hu/magyar/oldalak/bethlen_istvan_miniszterelnoksege/ Letöltés: 2018. március

Romsics, I. (2010). Magyarország története a XX. században. Budapest: Osiris Kiadó.

Web:http://www.tankonyvtar.hu/hu/tartalom/tamop425/2011_0001_520_magyarorszag_tortenete/a datok.html, Letöltés: 2018. március 16.,

Szabó, A. (2008). A trianoni Magyarország "kultúrgeográfiai térképe". Földrajzi Értesítö, LVII, 435-449. Letöltés: 2018. március 16., Web: http://www.mtafki.hu/konyvtar/kiadv/FE2008/FE20083-4_435-449.pdf

Ujváry, G. (2012). Pozitív válaszok Trianonra. Klebelsberg Kuno és Hóman Bálint kultúrális politikája. Korunk, 23. évf., 66-75. Letöltés: 2018. április 12., Web: http://epa.oszk.hu/00400/00458/00586/pdf/EPA00458_korunk_2012_11_066-075.pdf 